\title{
DRUNKARDS AND SINGERS: A MONGOLIAN BATTLE OF SOUNDS
}

\author{
LAURENT LEGRAIN \\ FNRS Postdoctoral researcher \\ Université Libre de Bruxelles \\ 44, av. Jeanne 1050 Bruxelles \\ e-mail: Laurent.Legrain@ulb.ac.be
}

\begin{abstract}
When I conducted fieldwork among the Darhad of northern Mongolia my informants repeatedly asserted that after a good singer's performance even the most badly intoxicated lad stands still and keeps silent. In this article, I make three points in order to explain why this claim was made. In the first one, I show that the main concern about singing performance at social gatherings is not about revealing the singer's inner emotional realm but rather about crafting a collective feeling that has the ability to make people temporarily shed their otherness and converge. The problem with drunkards lies in the fact that they are unable to participate and even noisily impede this rite of convergence. The main reason is that they are not sufficiently detached from their own inner realm. I then put the concept of noise in context, arguing that it forms the repulsive pole of a Mongolian sonic continuum. In my last point, I stress the fact that according to Mongolian linguistic ideology, noise brings misfortune to the entire community. That is why good singers must win their battle against drunkards.
\end{abstract}

KEYWORDS: Mongolia $\bullet$ songs $\bullet$ linguistic ideology $\bullet$ alcohol $\bullet$ otherness

\section{INTRODUCTION}

Speaking about songs and alcohol in Mongolia makes us travel along a complex network of intricate connections. At every feast you will come across during the summer and autumn months, you will be expected to sing after being offered airag (fermented mare's milk, an alcoholic beverage that may contain 2-3 per cent alcohol), tsagaan arhi (a much stronger homemade alcoholic spirit distilled from milk) or vodka. It may happen that you sing well and charm the musical ears of your audience. In this case, you will be praised and offered more drinks. In the 1990s, a very famous singer named Peljeegiin Adarsüren (1942-1998) became totally addicted to vodka. His numerous fans took the blame for it and were ashamed of having paid tribute to his talent through countless offerings of alcohol. In a novel called Av'yaas ('Talent') the novelist D. Batjargal told a very similar story about a skilful dancer in the grip of alcohol who fell asleep in the street on a freezing night. He survived but had to undergo amputation of his right arm, which prevented him from getting on stage (Batjargal 2005: 92-99). Once again, the main culprit was public admiration. In a recent publication on Adarsüren's career 
(Amartaivan 2013: 6), the Mongolian poet and journalist B. Tsenddo stressed the fact that the singer's intoxication began during the socialist period when people did not have anything special, anything outstanding, anything worth offering to Adarsüren except alcohol. Yet this explanation is one sided only and does no justice to the enduring role alcohol has been playing in the "cultural framework of respectful giving" to exceptional people as well as to the spirits (High 2008: 187).

As far back in history as we can go, manuscripts tend to show that, among Mongolian people, alcohol was not considered the product of human labour alone. Rather, fermented mare's milk was regarded as the index of a good relationship between spirits (most often gazryn ezed 'masters of place') and humans. The former bestow blessings in the form of rain and favourable weather condition and the latter pay tribute through offerings as well as entertaining spirits with their manly games and their joyful sociability, a sociability that includes the performance of many songs. Airag - later vodka and other distilled beverages - are thus "positioned within a recursive relationship based on acts of giving between humans and spiritual beings", as Mette High (ibid.: 185) cogently puts it. Offering alcohol to famous persons can be viewed as a translation of this general principle.

In this paper, I wish to investigate further this web of connections and ask one question that might seem at first sight anecdotal (actually it might seem anecdotal even after giving it a second thought if my argument fails to convince you). Why do my informants repeatedly assert that after a good singer's performance at wedding ceremonies and other meetings, even the most badly intoxicated lad within the audience stands still and keeps silent? Practically, all my main interlocutors have somehow mentioned this amazing power of singers' voices. During my fieldwork, I heard these comments again and again. For example, Davaaji - a sixty-year-old herdsman - remembered the voice of a famous Darhad singer: "The people around were unable to chat when Baasanjav was singing", he pointed out to me. What he meant, and later made explicit, was that even the drunkards were unable to raise their voices as Baasanjav's voice was filling the entire space.

In Mongolia, drunkards are said to be noisy - sometimes as noisy as Chinese people - and in addition to this already frowned upon sonic behaviour, they talk with no reason, just for the sake of talking (demii yarih) in a country where, generally speaking, silence is golden. ${ }^{1}$ This battle of sounds between drunkards and singers is hardly new. J. Dorjdavga, a famous singer who entered the Mongolian art world in the 1950s, recalled how he was taken aback when listening to the powerful voice of his master M. Dugarjav (1893-1946, the father of the Mongolian modern music): "He sang until no other sound except his own came out", and again later in the same conversation Dorjdavga made an explicit reference to the idle talk of drunkards (sogtson uls) (Badraa 2005: 138-139).

The question these comments leave me with is why should it be so important for a singer to shut drunkards up? Enduring behaviours and repeated statements ring in the ears of anthropologists and might tell us something novel about sound, sociality, alcohol and morality in drinking. My interlocutors framed the issue as if it was a kind of sonic battle. Let me stick with this view in order to set the general outline of the paper. Therefore, after having described the social topology of the 'battlefield', I shall introduce the two opponents: the crowd of drunkards on my left and the outstanding singers on my right. As the first section will make obvious however, singers may be a 
bit tipsy or even totally drunk and that very fact will right away confuse the issue, but also make it more appealing. I guess life is baroque anyway, although certainly not to an extent to which the world would become impenetrable.

\section{AT SOCIAL GATHERINGS}

From 2001 to 2011, I carried out 20 months of fieldwork among the Darhad, an ethnic minority in northern Mongolia. I resided mainly in the village of Rinchinlhümbe, which is in the centre of the district of the same name, in the eastern part of the Darhad valley (darhadyn hotgor). Half of the district population (more or less 5,000 people in total) dwell in the village in winter and the other half reaches the deep valleys situated in the mountainous area west of Hövsgöl lake (see Figure 1). There, they are sheltered from the icy wind and raise livestock (mainly yaks, sheep and goats). Many celebrations take place during autumn (a three-month period stretching from July to September) when the products of livestock herding (meat, milk, and milk alcohol) are abundant.

In this paper, I aim to deal with social gatherings in general, although the ethnographic material upon which I shall build and substantiate my argument consists of a description of a wedding celebration that evolved into a bloody brawl. I have witnessed eruption of fights related to alcohol consumption and songs many times in every genre of domestic celebrations (nair), ${ }^{2}$ even when these nair were on the occasion of daily hospitality like a simple visiting situation that morphed into a feast. What I want to underscore lies, I guess, in the very nature of social interactions that take place during such situations in which people seize on "the interaction's own contradiction of closeness across political divides" as Rupert Stasch (2009: 45) terms it when he analyses host and guest interactions among the Korowai people of Papua New Guinea.

In a situation of host-guest encounter, two sets of people are in each other's presence, and this alone creates and confirms a sense of connection between them. But their presence to each other also focuses attention on their mutual strangeness. (Ibid.: 50)

What I have in mind is quite similar. People are indeed different. Even the closest kin experience differences on a day-to-day basis (be they political, hierarchical, relational, gender or age based as well as intention related, etc.). The force of the bond that will make up a collective from this collection of differences "rests in the risks and vulnerability people overcome together by relating across [...] divide[s] between them" (ibid.: 54). Needless to say, bounding is always a gamble that can be lost or won. It may seem to be an obvious consideration but reading High's deeply insightful monograph, Dangerous Fortunes (2008), I was left with the impression that brawls and fights were only present among ninjas (illegal miners who dig the steppe in search of gold) while, on the contrary, highly formalised interactional scripts make it possible, in rural areas, to avoid slipping into uncontrolled mess.

As for my ethnographic context, brawls and arguments arise quite often even when people carry out a set of prescribed actions they call rules (yos) (Humphrey 2012), a very "formalized hospitality". I will start from the assumption that the 'ideal world' constructed through the enactment of hospitality - which in Mongolia always includes 


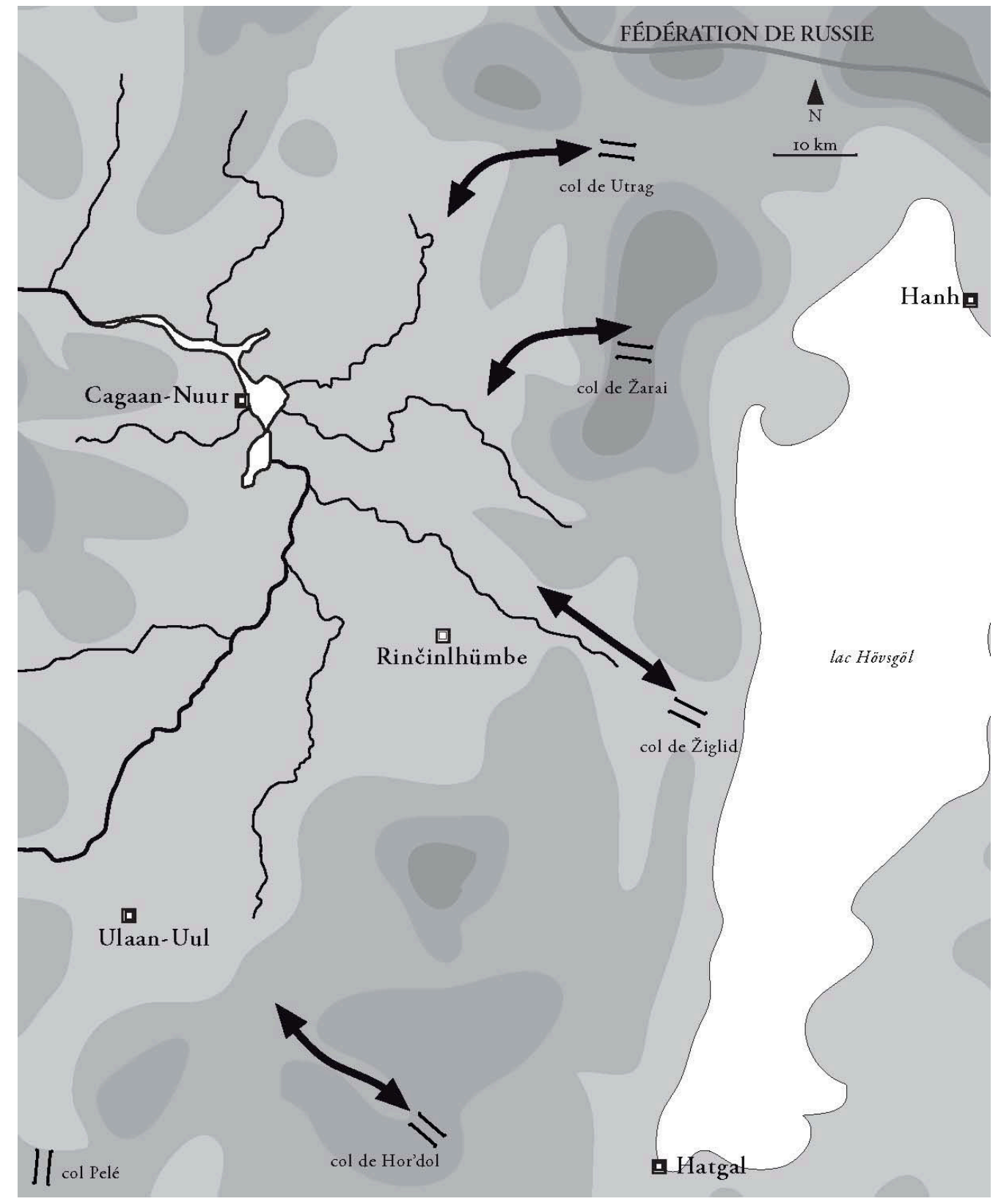

Figure 1. Map of the Darhad valley by Marc Alaux.

ceremonial drinking - is fragile, "momentarily upheld and easily overturned", as Mary Douglas reminds us in her introduction to Constructive Drinking (1987: 12). Being in the countryside for a long period of time, I was involved in quite many brawls to a greater or lesser extent, in spite of everything. While running away, I came to understand that violence breaks out precisely because the establishment of a "peaceful sociality of hierarchical differentiation" implies the relentless work of many actors who bring with them 
their otherness. What role do alcohol practices, drunkards, singers and sounds play in establishing the very possibility of being packed together for hours with people, some of whom are increasingly intoxicated, all of whom are in many respects separate from each other by their seniority, status, gender, intention, affiliation, personal history and so forth. Talking about weddings, Caroline Humphrey metaphorically describes these events as a "sea-swell of underlying agonistic currents of social precedence, rivalry, honor, ambivalence, enmity, aggression and fears" (Humphrey 2015). The following depiction supports her view. It was written several years ago when I carried out fieldwork among the Darhad of northern Mongolia, but I am sure that it could have been observed in many other places in Mongolia.

In November 2005, the members of my host family and I were attending a distant relative's wedding ceremonies. All of us had already sung in turn when the master of the ceremony invited us to stand near the fire, drink airag and appointed us to sing. The bride had lit the fire in her brand new ger (the Mongolian round felt tent) erected near her father-in-law's log cabin. I did not pay much attention to my host's grandmother, but when I caught a glimpse of her I realised that she was totally drunk. Not surprisingly, as the song of a young girl was filling the space of the ger where we were tightly packed together, Büree (the grandmother's nickname) started weeping loudly, oblivious to the reproaching glances people were casting at her and refusing to hear the comforting words whispered by her neighbours. She was dissolving into noisy tears, so much so that even the young girl standing in the middle stopped singing. There was actually nothing unusual so far. The first time I was invited to a wedding, I asked a very perceptive six-year-old boy what to expect and he replied: "You will sing, you will weep, you will drink and you will fight!" But in this case, things really went amiss. Büree's daughter was attempting to grab her, pulling her glowing gown in a desperate attempt to drag her outside the ger. The grandmother lost her balance and fell on some elderly people in the first row. Vodka and milk were spilling out while dishes were falling from the front table. The few helpful arms that kept on supporting her let her drop. She was then lying on the wooden ground, her face wet with tears and drool. The overall picture was driving her daughter crazy. She was yelling a lot and hitting her mother, insulting her, dragging her hard to the door. Büree was shouting the name of her sister who died a long time ago at around the same age of the girl who was singing. At the same time, on my left a fight was breaking out between two men, then three, four... A young guy grabbed me with force shoving us towards to door. Before I freed myself from this mess, I caught a glimpse of the bride and bridegroom sitting immobile, emotionless, on their brand new sofa. Shouts, cries and brawling noises continued for a while before slowly calming down. We saw many men, and one woman, with blood on their faces emerging from the ger. Outside, fights were breaking out again, this time they were quickly handled by young guys who managed to push them away from the encampment. The master of the ceremony (quite drunk too) was uttering something that sounded like an invitation to go and sit back inside. I was looking at the bride halfsmiling at me. Someone started singing and the hostess was pouring vodka into the glasses of her guests. No traces of Büree and her daughter. The show was going on... 
"There is more pleasure in sitting than in drinking and more pleasure in singing than in sitting" (uuhaas suuhyn bah suuhaas duulahyn bah). The lesson to learn from this Mongolian saying is that, at large gatherings, singing (either taking the lead when the master of the ceremony appoints you to sing or singing along with the one who has started singing) forms the desirable behaviour far more than being simply there or getting drunk. The reality is however rather different since the person who sings is also the person who is urged to drink. The general meaning of the saying may be best understood not as a condemnation of alcohol consumption but as a call to contribute - no matter how drunk you are - to the crafting of a "joyous atmosphere" (Humphrey 2012: 73), of a nostalgic or sad feeling or whatever feeling you want to concoct as long as it is geared towards shaping a collective atmosphere, "a rich sensorialized sociality" (Chau 2008) suffused with the particular feeling encapsulated in the song you choose. Concocted feelings do not need to be felt to exist. They are enacted "through the use of performed techniques" (Humphrey 2012: 74) like songs. You do not need to be sad to sing a sad song. Unlike some European music teachers, most of the time Mongols do not require such correspondence between the feeling you craft when singing and the emotion you actually feel ${ }^{3}$. And still, even if you do not feel sad, even if no member of your audience feels sad, sadness hangs in the air, in the melody, in the lyrics, in the singer's gestures. Sadness is now a constitutive element of the feast, a temporary landmark, an atmosphere that may or may not make people shed their otherness and converge on the same emotion. But again, no matter if they do converge, the feeling is there anyway and again, no matter how drunk you are, you are expected to contribute to the crafting of the different feelings that will follow one another as each person performs a song. If I were to contrast this ideal view I would say that being drunk and singing during a nair is exactly the opposite of what it means to get drunk among the Evenki. According to Tatiana Safonova and István Santhá (2013), heavy drinking practices among Evenki can be partly understood as a way to reach a manakan state of being within which people are totally disentangled from any commitment with others. In contrast, as I have already emphasised, you might get drunk at a Mongolian celebration without anyone complaining about it as long as you are able to participate in the "rite of convergence" (Chau 2008) that each song sets up one after the other. In order to achieve this, you must be aware that the song you are performing or the song you are listening to is first and foremost geared towards the introduction of an atmosphere that allows people to stay together despite their many differences, their otherness and strangeness.

Mongols hold that traditionally, at celebrations, people exclusively sang long songs (urtyn $\mathrm{duu}$ ), the most respected and presumably more ancient vocal repertoire of Mongolian music. Long songs are an exercise of vocal virtuosity. Each syllable of the lyrics is extended and finely chiselled through modulated vibrato, vocal modulated pulsation, and glissando. ${ }^{4}$ Despite this repeated statement about long songs my ethnographic data makes obvious another reality. Even though elders normally open a formal ceremony with a long song, most of the time people sing authored songs (zohiolyn duu), current musical productions recorded in Ulaanbaatar. A huge number of the melodies use pentatonic scales arranged in narrow tessitura; so much so that everybody can sing it without too many problems. Successful songs may include short sections in which 
the singer can let his or her voice sound on extended vowels at the end of a verse. The lyrics depict deep love between men and woman or the pleasure of being together. They praise motherhood in respectful words suffused with a tinge of nostalgia when the song is sung by adults. Lyrics speak about the scenic Mongolian landscape and the excitement you feel when riding a horse through the steppe. Roughly speaking, lyrics portray a totally sublimated countryside smooth life. For example, the song the girl sang when my host grandmother interrupted her was a hugely popular success at that time, and went like this: ${ }^{5}$

Uugaad suuhad min' uram sergeesen

Uuguul nutgiin min' amttaihan tsai

Olon tümnii undaa $n^{\prime}$ bolson

Orchlond gantshan eejiin miin' chanasan tsai

Comfortably sitting, I sip it and I get my strength back

The tasty tea of my native land

Has become the drink of the masses

In the entire universe, the only thing that counts is the tea my mother has been making for me

While performing this kind of song at a social gathering, what matters is not to get lost in singing but to be aware of the feeling that is crafted. Mongols, I believe, are less likely than other people to consider the song as an act of expression. No one would ever accuse anyone of not being sincere when singing. No one would say to the girl: "Why do you sing it as you are widely known to be a real problem child who shows no respect to her mother". And if someone had asked the question, the girl would have answered: "Because I can sing it well". There is no imperative to achieve a correspondence between an emotional inner realm and a performed song. The importance is to produce a rich sensorialised sociality full of sounds that piques the senses (see below). Two decades ago, the Mongolian composer G. Birvaa (1989: 129) wrote "through a melody it is possible to bring into harmony (or to adjust) people's emotions" (hünii setgeliin hödölgööniig uran ayalguugaar zohitsuulna). When speaking of performance at social gatherings, Mongols often use verbs like zohitsuulah ('bring into harmony'), niilüüleh ('co-opt' or 'adjust'), evlü̈̈leh ('assemble', 'fit together', 'piece together'). The general idea that emerges from these verbs does not focus on an act of expression. Rather what can be deduced from this list is that songs must be performed to create a common atmosphere that allows a temporary adjustment of differences, not their erasure; not the merging of these differences or conversion into a unique emotional state, but rather their piecing together.

That is why in such context, songs can be viewed as a way of being detached in Humphrey's meaning of the term. Detachment, Humphrey (2015) notes, must not be confused with distraction, irony or aloofness. To be detached means to be fully aware of what is going on and this form of attention requires distance from one's own perspective. Singing, it seems to me, is just the perfect technique for enacting detachment. Songs do not belong to anyone present at the gathering and have the power to sonically fill the space and the capacity to set a collective atmosphere. As previously stressed, you are not required to be lost in the mood that a song conveys (although you may as well). But what would certainly be regarded as a breach in the rite of convergence 
is the cutting off, for personal reasons, of the collective effort to generate a feeling. So, "Detachment is fragile" as Humphrey puts it (ibid.: 152) and perhaps especially as people become increasingly intoxicated. The above depiction is a blatant example of this. My host grandmother was unable to stand back from her own emotion and upset the feeling of respect that the girl's song - a song about filial piety - was striving to achieve. Büree's sadness encroaches inappropriately upon the general atmosphere. It is not that the expression of sadness is inappropriate during a celebration (be it a wedding, a child's first haircut, a visit or any form of social gathering). Rather, the problem lies in the very fact that it is an isolated expression of crude emotion, not geared towards the crafting of a collective atmosphere at all. And therefore this 'hiccup', and all the fuss it caused, released the underlying currents of amenity and rivalry that were still there but kept under control by a collective endeavour. If the girl's song had been a sad song, and the weeping grandmother less extravagant, it would probably have passed without notice. The people sitting next to Büree would have consoled her and if that had not been possible - a strong signal that she couldn't be minimally detached anymore -, would have gently take her out at the end of the song. The problem with badly intoxicated people is exactly that: they are often unable to be minimally detached and become increasingly encapsulated within their own emotional realm... and increasingly noisy. Singers work up the audience, sonically creating some potential source of convergence. Drunkards, intentionally or not, mess it up... sonically as well. In this sense, singers' and drunkards' behaviour increasingly diverges in their "active participatory role [...] as makers of the social sensorium" which means here "a sensorially rich social space", "a place full of sensory stimulations" (Chau 2008: 488-489). Adam Chau, who suggests this notion of sensorium, worked among Chinese people from rural Shaanbei. He emphasises how festivalgoers prefer a hot and noisy ( $\left.r e^{\prime} n a o\right)$ sensorium when celebrating their deity's anniversary (ibid.). Ideally speaking, Mongols would prefer to make it hot and melodic given their disgust for noise and their concern about the malevolent power of idle talk. In order to fully understand this point, let's have a look to Mongolian conceptions of their sonic environment.

ATTRACTION AND REPULSION:

\section{A MONGOLIAN SONIC CONTINUUM}

Singers sing songs (Duuchin duu duuldag). In Mongolian, the root morpheme duu means song, and many words are derived from it as the simple previous sentence shows. However, the semantic field of this morpheme is much broader than that. Duu also means human voice and some of the sounds produced by natural or spiritual entities. In fact, according to its definition the most encompassing meaning of the term $d u u$ is "sounds that arouse the hearing organs" (sonsoh erhtend seregdeh avian chimee) (Tsevel 1966: 213). And indeed, when a sound draws the attention, a person will choose the word duu from among other words that denote sounds, such as avia or chimee. Noise (shuugian), to the contrary, cannot be said to arouse the hearing organs. Of course, from an acoustic point of view, noises equally draw the attention of the listener, but the positive valence bestowed upon the verb sergeh ('arouse', 'awaken') makes it impossible to put it like that. In Mongolian, noise is what prevents the hearing organ from being fully deployed, 
vigilant and attentive to the matter at hand. Far from arousing the senses, noise is held to hamper audition. Here is a short example of a sound that first draws the attention of the listener before becoming an obstacle to clear hearing:

A few years ago, I was sitting with a young guy in the Tengis valley, very close to the taiga inhabited by the Tsaatan people. The Tsataan form an ethnic group who live in a mountainous and forested area in the Mongolia far north. Their way of life - they herd reindeer - has attracted lots of tourists and travellers for about two decades or so. Bataa (a teenager from a nearby district) and I heard a kind of roar. Bataa asked me "What makes this sound?" (jund duugarah ve?). A helicopter crowded with travellers landed five hundred metres away from us. When we arrived close to it, Bataa shouted "What a din!" (yamar ih shuugiantai ve!). In a matter of seconds, the roaring of the helicopter had moved from one pole of a sonic continuum duu to the other extreme - noise (shuugian). This move was caused by a change in the impression left by the sound: from a sonic event that was worth considering to a noise covering all the soundscape and preventing Bataa from hearing or, in other words, from something prompting awareness to the sonic environment to something that sonically precluded any real attention to what was going on (Legrain 2014a).

In general, all that is termed noise causes disgust, particularly when relating to language use. Parents try by every means to impress upon their children not to be noisy, the importance of being cautious about not speaking too much and certainly not interrupting adults speaking or even catch the attention of elders for too long. Here is a short example that reveals this concern: In Mongolia, people have a particular attraction for the beauty of children's clear and high-pitched voice. The basic classification for it is therefore duu (hühdiin duu 'children's voices'). One evening in a rural village in northern Mongolia, Mönhbayar was watching television. Two of his sons (6 and 8 years old) began to quarrel. After the first admonishment the boys kept on making a noise. Unable to watch his program, Mönhbayar leapt out of his chair and shouted "Stop banging around!" (Bitgii chalchaad bai!). The term chalchaa has a very negative connotation. A chalchaa is a person who likes to talk for the sake of talking (demii $\ddot{u} g$ yarih durtai). After giving his order Mönhbayar repeated continuously the first syllable of the word "chalchalchalchal..." and in doing so, gave a sound representation of how the children's chattering impacted him: pure noise without any coherence or any meaning. His youngest son, who tried to warrant his conduct, bumped into this wall of sound and gave up his lament. This kind of sonic behaviour is termed noisy (shuugiantai) and is severely frowned upon.

One may say that singers are the masters of the $d u u$-side of the soundscape while drunkards tend to shift from one side (attractive sounds) to the other (disgusting noise). In addition, besides being deeply disliked, noises can have harmful consequences for the community as a whole, as I will discuss in the last two sections of this paper.

\section{DRUNKARDS AS RADICALSTRANGERS AND AS VESSELS FOR EVIL SPIRITS}

To be honest, with drunken people around, you are sometimes in good company. It can happen that they sing very well. They quickly lose their initial shyness and their 
voice soars in the most natural and engaging manner. Drunken people are also known for beautifully and comically interweaving truths and lies, telling stories that sound marvellous and captivate the audience. They can therefore make great contributions to any social gathering. When they do these things, they remain within the $d u u$-side of the sonic continuum. The problem arises when, for example, they do not remember the lyrics of the song they are singing or the punch line of a comical story they are telling. But, those are still minor matters. Most of the time people who sing along or listen to the story are covering theses tricks of memory universally caused by alcohol consumption and remind the singer or the storyteller of the lyrics or of the end of a story. However, the situation obviously worsens. When getting increasingly intoxicated drunkards become unable to speak without stuttering and stammering a lot, or even become unable to utter a simple sentence. They may also leap frenetically from one subject to the other in a way devoid of any meaning. Worse still, they may forget themselves and use totally inappropriate language, evoking the name of a deceased person and violate every language restriction, as did my host grandmother during the wedding ceremony.

In "Moral Drinking", a thought-provoking chapter of her PhD dissertation, Mette High delves thoroughly into the heart of the matter when she asserts that in Mongolia "speech carries exceptional potential for causing calamities" and that "a drunken man's talk can be dangerous", the latter statement being a straight quotation of her host father (High 2008: 191). Following High's argument, drinking at social gatherings is moral essentially because it provides a "forum that incorporates both ninjas [illegal miners] and chötgörs ${ }^{6 "}$ (ibid.: 206). With regards to ninjas, these fellows are most of the time common herdsmen who have broken the frame of rural sociality in search of gold in the nearby mines. They are said to earn money (sometimes a huge amount of money) by digging the ground, an action that is forbidden and can make the master of place (gazryn ezen) angry. Ninjas are portrayed as selfish people who refuse the give and take of herders sociability, and as abusers of hospitality. In this context, High considers social drinking a means used by ninjas to re-incorporate the herding household. Getting drunk or pretending to be drunk and acting like a drunken man, ninjas "display their familiarity with the appropriate drinking practices of herder and the cultural value they place on lying" (ibid.). ${ }^{7}$ In other words, ninjas integrate the role of the guest and turn the family they visit into the thoughtful host. The crux of High's argument is here. Overcoming the series of incidents a drunkard is likely to cause should be viewed as an opportunity to demonstrate group solidarity and togetherness. "[E]ven the most challenging situation never becomes an insurmountable threat to amicable living" (ibid.: 198). The same applies to spirits. Drunkards' behaviour - especially that which is known to invite harm, like shouting the name of a deceased person in the way my host grandmother did at the wedding celebration - actually reflect an ontological transformation. ${ }^{8}$ The drinker is now directed by a malevolent spirit that has taken control of him. But again, this radical and dangerous otherness that emerges in the middle of a social gathering is not an unbeatable challenge and will soon be overcome by a "harmonious, celebratory ideal" (ibid.), as the host displays and brings to life the multiple rules of hospitality. So, in the case of the wedding ceremony I described briefly above, the interpretation would be that in going to sit back inside the round felt tent, as the drunken master of the ceremony asked us to do, we claimed a temporary victory over the threatening spirit world. The smile of the bride, the glass of vodka I was offered and the song that we sang 
again together (although there was no trace of Büree when we resumed our seats in the ger) prove that the group succeeded in overcoming the challenge and claimed its unity. We (the humans present) won a battle we fought against evil spirits by incorporating their strangeness into a humanly made ideal.

I did not hear about chötgör the next day and even two days later when my hostgrandmother reappeared from a wooden log cabin that had been built for the occasion some hundred metres away. Of course, it is not because I did not hear about it that this interpretation of the situation was not there. The only thing that I know for sure is that what made Büree's reverse ontological transformation - from chötgör to human was simply a good night's sleep and had nothing to do with the performance of the group's togetherness. To be fair, I did not hear any comment after this dramatic event. People do not talk about such crises afterwards, although I still got the sense that no one was tasting victory. Surely enough, if I had chosen to speak about it with others as witnesses, my demeanour would have constituted misconduct, "a severe breach of social amity" as Rupert Stasch (2009: 51) has formulated it. Such situations occur and disappear, it may prove to be annoying, even quite dangerous, but the day after no one will make any remarks and things will apparently return to normal. I am convinced that this silence is related to a pervasive linguistic ideology according to which talking about something bad, something hurtful, will induce other bad events to happen, will place the entire community in the grip of misfortune and will lead the group to suffer greater harm.

\section{DRUNKARDS' CONVERSATIONS: THE DANGEROUS AND DISGUSTING SIDE OF THE SONIC CONTINUUM}

In this last section, I would like to delve a bit further into this Mongolian linguistic ideology. High's interpretation of the incident prompted by drunkards is fascinating and original and, in a sense, fits perfectly with the usual statement on the battle of sounds between singers and drunkards that my interlocutors pointed out many times over the course of my fieldwork. Singers whose role is to enhance a harmonious sociability must silence the drunkards who could be directed by evil spirits. Drunkards, being therefore not totally human anymore, stretch to the limit the other's strangeness. Singers' voices fill the entire soundscape and neutralise the harmful potential of drunkards who find themselves muzzled and deprived of language (their best weapon). However, in High's ethnography, speech acts are indeed potentially harmful although they seem to be quite easy to control. Apart from this, the dangerousness of language derives from the fact that it is used by chötgör, or, at least from ill-intentioned individuals. In this last section I will allocate greater force to Mongolian linguistic ideology and even to the purely sonic dimension of language without regard to the speaker's intention or to her ontological transformation.

Let me start by quoting Alan Rumsey's definition of linguistic ideologies based on Silverstein's work as "shared bodies of commonsense notions about the nature of the language in the world" (Rumsey 1990: 345), that is to say "any sets of beliefs about language articulated by the users as a rationalization or justification of perceived language structure and use" (Silverstein 1979). It should be noted that lots of cultural reflexive 
conceptions about language use that linguists highlight everywhere in the world are less concerned with the information conveyed in the language than with the many ways in which the speech act impacts upon the world. The Mongolian case is a perfect example of this pervasive concern. Yet let's look first at an example in which the information language conveys and the way language affects the world seem to be interrelated:

It sometimes happened that I was the only adult present in my host family's ger. When Davaasüren and Mönhbayar came back from some distant place, they invariably asked me to list the name of the visitors who called while they were out. One day I answered: "The man who speaks like a woman". Mönhbayar laughed but Daavasüren lost her temper. "No one could speak like that," she wailed. "What is the point of using poisoned words? It is said to be a bad sign for him [the man who speaks like a woman]!"

Talking about people behind their backs is a clear means of influencing their lives in various manners, but more often than not, in a negative way. As Roberte Hamayon and Namtcha Bassanoff (1973: 70) have argued, to talk about someone means to have a grip on that person. The malevolent power of curses and gossip comes from this conception of the working of language in the world. Gossip risks bringing calamities upon the speaker and upon the person being spoken about. Speech can indeed be dangerous and it "achieves its potency from both the actual content of the utterance and the very act of speaking", to quote High again (2008: 191). In the regional ethnographic literature, the malevolent power of words is quite well documented. More ethnographic material allows me to probe this issue further. The next example depicts the speech act of a young boy, an act that will be considered potentially harmful despite the fact that the he just wanted to make his audience laugh.

Most of the time, Mönhbayar is a calm and thoughtful father. Sometimes the slowed and slurred speech of his eldest son (Bumbayar, 7 years old), his faltering voice, the noises he makes with his mouth, drives Mönhbayar crazy. On numerous occasions, I saw him making desperate efforts to keep his son's speech problem in proportion. "It will vanish when Bumbayar grows up", he often remarked to me. One day, however, Mönhbayar flew off the handle when hearing Bumbayar intentionally making an ass of himself in front of the other children of the encampment. The little boy was singing a well-known pop song parroting his own slurred speech to his relatives' greatest delight. His father rushed out of the ger and punched his son's face (an act generally frowned upon in Mongolia). He dragged him inside his ger shouting and complaining that "his own son was a fool unable to speak properly".

How can we understand Mönhbayar's terrible anger? It is obvious that oratory skills are still crucial in Mongolia and constitute part of what it means to be fully adult. However, a few days after this occurrence, I talked with Davaasüren, Mönhbayar's wife. She explained to me that, as far as she knew, Mönhbayar's concern at that time was not the future of his son. With regard to that, Mönhbayar was quite confident. No doubt Bumbayar will become a skilled herdsman. "But", continued Davaasüren - becoming increasingly nervous - "to speak like Bumbayar is bad (muu) not only for him but possibly for all the family". "Bumbayar's chaotic speech" - Davaasüren imitated the noises he usually makes (most of the time unwittingly) - "is without order (zambaraagüi) and may have bad consequences for all the member of the family (manaid muu)". She said countless other things that I did not understand, but from her sudden flow of sentences I knew that Davaasüren was deeply moved and that unfortunately it was no use asking her explain to me what she meant exactly. 
The lyrics Bumbayar sang - a beautiful poem praising motherhood - were meaningful as he made only a cover of a famous song. We may thus assume that the problem lay only in the speech act and more precisely in the prosodic elements of this speech. Perhaps Mönhbayar's anger might be understood as an implication of the first basic tenet of Mongolian language ideology: speech is an act that affects the world. But here, the malevolent power is not hidden in the meaning of the lyrics. How could that be? The song is a national hit that depicts mother's devotion to their children. What makes the song potentially harmful is the utterance. To follow Davaasüren, it is the disorder of the speech act that turns these beautiful lyrics into an uncontrollable danger. What I would suggest here is that the Mongolian linguistic ideology blurs the distinction between on the one hand the order of the language and on the other hand, the order of the world. Therefore this conception equates the introduction of disorder within the language with the introduction of disorder within the course of the world. That is precisely what should be avoided by imposing silence on drunkards and by settling a perfectly ordered soundscape through well-sung songs.

\section{BY WAY OF CONCLUSION}

Following Stasch's (2009) analysis, I have assumed throughout this paper that "otherness is the crux" of any social gathering be it as large as a wedding celebration or as small as domestic celebrations. Any social gathering involves alcohol consumption as well as performances of songs. Regarding songs, it is widely assumed in many different cultural settings that a good performance must reflect a singer's emotional inner realm. This conception, however widespread, is by no means universal. In the thick of the Mongolian celebrations, singing is rather held as an act aimed towards others. It may reflect your own emotional state but it is, first and foremost, geared towards the crafting of a feeling, the role of which is to sonically fill the place and thereby to offer to everybody present a potential source of convergence. That is where Humphrey's (2015) conception of detachment and Chau's (2008) notion of sensorium play out. Detachment is a "quality of action" which has nothing to do with indifference. To be detached in Humphrey's sense means to be able to distance oneself from one's own perspective for beneficent ends. In the case at hand, being detached means choosing a song that is not yours, which does not specially reflect your own current emotion but that is known to give a beautiful picture of Mongolian life. While singing it you will try to make it sound the best you can. In doing so, people demonstrate their mastery of vocal techniques, produce sounds that are worth hearing, reveal the atmosphere encapsulated in the lyrics and, above all, make this atmosphere concrete, materially present. What is of great importance here is to use something that is common to all, a song, a poem, a wellknown story and contribute to the construction of a common social sensorium, "a place full of sensory stimulations". Partaking in producing this sensorium certainly makes people feel that "they are in the middle of a satisfying, 'hot' event" as Chau (2008: 488) puts it, but, in addition, this common endeavour covers up people otherness, which continues, at least potentially, to pose a threat to the smooth continuation of a celebration. They stay together, possibly enjoying it, under cover of a collective feeling. 
To some extent, consumption of alcohol supports this process. Offering alcohol is also an act towards others, a way of connecting people who are separated by their differences. Alcohol and drunkenness allow people to shed quickly their social inhibitions. Drinking is, in Mongolia, a massive social fact that creates many opportunities for people to socialise and therefore many opportunities to hear new songs, new stories they will sing and tell at other celebrations. The problem arises when people become so intoxicated that they are unable to speak, instead they chat continuously, irrespective of what is actually going on, talk nonsense or, worst of all, use language that is totally inappropriate. Universally, alcohol intoxication affects language skills but in Mongolia, language is what makes you human and the loss of language abilities is what turns you into an animal (Bianquis 2012: 133; Lacaze 2012: 198) or a chötgör (High 2008) when you are too drunk to speak or to understand what your fellow humans try to tell you. Moreover, I have argued that a pervasive linguistic ideology equates disorder in language with disorder in the world, bringing misfortune, intentionally or not.

High has told us that among the ninjas of Central Mongolia, a rumour is circulating. It goes like this: after drinking with strangers who added undiluted industrial alcohol to his drink, a man "wakes up hours later with a non-responsive tongue, paralyzed by the strong alcohol. As the tongue apparently never recovers, [the guy] becomes subject to intense ridicule and social ostracism." (High 2008: 202) In Mongolia, the sounds you produce make you handsome, affable, cheerful and beautifully detached but they can also make you ridiculed, disgustingly noisy and even dangerous. Drunkenness plays a part on both sides of this continual process of becoming an admired or feared sonic being.

\section{NOTES}

1 A Mongolian saying states, "The mouth of the cuckoo that sings first freezes" (türülj duugarsan höhönii am hölddög). One of the general maxims that frame daily conversation could be summarised as follows: "Keep information about you to yourself" (Legrain 2014b).

2 There are many opportunities to set up a celebration: the erection of a new camp, a child's first haircut, the distillation of the first airag, anniversaries of local institutions, the arrival of an unexpected and respectful guest or a simple visits of relatives or friends.

3 You do not need to be sad to sing a sad song. In contrast to this, Kurdish women who sing Kilams about pain must, in order to affect their audience, "have personally and bodily been exposed to experience of pain, grief and suffering" (Schäfers 2015). As I am going to show, singing in Mongolia is not primarily about "transforming [an emotion] residing inside the body into an exterior form" (ibid.), but rather about making a social gathering enjoyable, pleasant, or at least satisfying.

4 A good version of the long song The Old Man and the Bird (övgön shuvuu) can be heard on YouTube (Mongol ardyn urtyn duu 2011). Lhamjav, the singer, is accompanied by a musician playing a horse-head fiddle.

5 On YouTube, S. Javhlant, a famous singer, sings the above song for all the Mongols who live in the US and miss their country (see Eejiin chanasan tsai duu 2014).

6 "A chötgör is the unsatisfied, offended soul of someone who died a 'bad death' (suicide, wrongly executed, died too young, etc.)" wrote Humphrey (2012: 72). High specifies that, "whereas some chötgörs are identified as the souls of particular people, others seem to be an abstracted source of evil intent" (2008: 193). 
7 For a deeper analysis of the cultural value Mongols place on the act of lying, see Legrain 2014b.

8 Morten Pedersen (2011) produces a subtle interpretation of violent crisis due to alcohol intoxication among the Darhad. What should be an ontological transformation from shaman to spirit turns to violent crisis (called the agsan state) because these people, not quite shamans, are unable to fully embody their shamanic spirits.

\section{REFERENCES}

Amartaivan, A. 2013. Ar Mongolyn aldart duuchin Peljeegiin Adaarsüren. Ulaanbaatar.

Badraa, J. 2005. Ih duuchin yaria. Ulaanbaatar: Admon.

Batjargal, D. 2005. Darhadyn bodol. Ulaanbaatar.

Bianquis, Isabelle. 2012. L'alcool. Anthropologie d'un objet frontière. Paris: L'Harmattan.

Birvaa, G. 1989. Mongol ardyn aman ayalguuny tuhai tovč ögüüleh n'. - Mongolyn högžim sudlal, edited by N. Žancannorov. Ulaanbaatar: State Publishing House, 125-138.

Chau, Adam Yüet. 2008. The Sensorial Production of the Social. - Ethnos 73 (4): 485-504. DOI: https://doi.org/10.1080/00141840802563931.

Douglas, Mary, ed. 1987. Constructive Drinking. Perspective on Drink from Anthropology. Cambridge; New York, NY; New Rochelle; Melbourne; Sydney, Paris: Cambridge University Press; Editions de la Maison des Sciences de l'Homme.

Eejiin chanasan tsai duu. 2014. https://www.youtube.com/watch?v=3JvUSQSHSnw (accessed November 24, 2016).

Hamayon, Roberte and Namtcha Bassanoff. 1973. De la difficulté d'être une belle-fille. - Études Mongoles (4): 7-74.

High, Mette. 2008. Dangerous Fortunes: Wealth and Patriarchy in the Mongolian Informal Gold Mining Economy. PhD dissertation. Cambridge University.

Humphrey, Caroline. 2012. Hospitality and Tone: Holding Patterns for Strangeness in Rural Mongolia. - Journal of the Royal Anthropological Institute (Special issue: The Return of Hospitality: Strangers, Guests, and Ambiguous Encounters) 18 (1): 63-75.

Humphrey, Caroline. 2015. Difference, Separation and Detachment: Lévi-Strauss at the Wedding Feast. - Detachment. Essays on the Limits of Relational Thinking, edited by Thomas Yarrow, Matei Candea, Catherine Trundle and Joanna Cook. Manchester: Manchester University Press,151167.

Lacaze, Gaëlle. 2012. Le corps mongol. Techniques et conceptions nomades du corps. Paris: L'Harmattan.

Legrain, Laurent. 2014a. Chanter, s'attacher et transmettre chez les Darhad de Mongolie. Collection Nord-Asie 4. Paris: EPHE.

Legrain, Laurent. 2014b. Les soixante-dix mensonges de Dalan Hudalc. La littérature orale et le mensonge au quotidien en Mongolie. - Journal Asiatique 302 (2): 467-483.

Mongol ardyn urtyn duu - Uvgun shuvuu hoyor 2011. https://www.youtube.com/watch? $\mathrm{v}=\mathrm{c} 3 \mathrm{aC}$ nO1uGpQ\&index=2\&list=PL0FE4310D134FF5EE (accessed November 24, 2016).

Pedersen, Morten A. 2011. Not Quite Shamans. Spirit Worlds and Political Lives in Northern Mongolia. Ithaca, NY; London: Cornell University Press.

Rumsey, Alan. 1990. Wording, Meaning, and Linguistic Ideology. - American Anthropologist 92 (2): 346-361. DOI: https://doi.org/10.1525/aa.1990.92.2.02a00060.

Safonova, Tatiana and István Sántha. 2013. Culture Contact in Evenki Land. A Cybernetic Anthropology of the Baikal Region. Inner Asia Series. Leiden; Boston, MA: Global Oriental.

Schäfers, Marlene. 2015. Singing with a "Burning Heart": Making Kurdish Female Subjectivities in Turkish Kurdistan. PhD dissertation. University of Cambridge. 
Silverstein, Michael. 1979. Language Structure and Linguistic Ideology. - The Elements: A Parasession of Linguistic Units and Levels, edited by Paul R. Clyne, William F. Hanks and Carol L. Hofbauer. Chicago, IL: Chicago Linguistic Society, 193-247.

Stasch, Rupert. 2009. Society of Others. Kinship and Mourning in a West Papuan Place. Berkeley, CA; Los Angeles, CA; London: University of California Press. DOI: https://doi.org/10.1525/california/9780520256859.001.0001.

Tsevel, Ya. 1966. Mongol helnii tovch tailbar tol'. Ulaanbaatar: State Publishing. 